\title{
Uncertainty and Business Cycle: A Review of the Literature and Some Evidence from the Spanish Economy
}

\author{
ROBERTO BASILE ${ }^{\text {a }}$, ALESSANDRO GIRARDI ${ }^{\text {b }}$ \\ a University of Campania “Luigi Vanvitelli”, Corso Gran Priorato di Malta, 81043 Capua, Italy. E- \\ mail: roberto.basile@unicampania.it \\ b Parliamentary Budget Office, Palazzo del Seminario (S. Macuto), Via del Seminario, 76, 00186 \\ Roma, Italy. E-mail: alessandro.girardi@upbilancio.it
}

\begin{abstract}
The article reviews the main economic mechanisms which have been theorised when considering the uncertainty/economic activity nexus, as well as the methods by which uncertainty is commonly proxied through observable quantities. Some empirical evidence on the role of uncertainty in shaping macroeconomic fluctuations for the case of the Spanish economy is also presented. We document that uncertainty tends to reduce the level of economic activity in the short run, although traces of overshooting cannot be detected.
\end{abstract}

Keywords: Uncertainty, Business and Consumer Surveys, Vector AutoRegression, Spain.

\section{Incertidumbre y Ciclo Empresarial: Revisión de la literatura y evidencia en la economía española}

\section{RESUMEN}

Este artículo revisa los principales mecanismos económicos que se han esgrimido a la hora de considerar el nexo incertidumbre/actividad económica, así como los métodos mediante los cuales la incertidumbre es aproximada por medio de cantidades observables. También presenta evidencia empírica relativa al papel de la incertidumbre en la configuración de las fluctuaciones macroeconómicas de la economía española. Se observa que la incertidumbre tiende a reducir el nivel de la actividad económica a corto plazo, aunque no se detectan signos de sobrereacción.

Palabras Clave: Incertidumbre, encuestas a empresas y consumidores, auto-regresión vectorial, España.

Clasificación JEL: E32, E37

Artículo recibido en octubre de 2017 y aceptado en enero de 2018

Artículo disponible en versión electrónica en la página www.revista-eea.net, ref. ə-36121 


\section{INTRODUCTION}

It is widely understood that heightened uncertainty can alter the decisions of private agents. Economic theory suggests that increasing uncertainty induces "wait-and-see" behaviour by firms and precautionary savings by consumers, resulting in reduced levels of investment, employment and consumption. Conceptually, uncertainty is different to risk. Uncertainty arises when economic agents are not able to appraise the likelihood of future states of the economy owing to the lack of information or knowledge, especially in times of economic and financial turmoil. By contrast, risk defines a situation where agents are able to assign probabilities to possible future states so that can be quantified and, eventually, minimised, as opposed to uncertainty which is hardly measurable. It is not surprising that the sequence of major crisis events like the Great Recession of 2008-2009, the European sovereign debt crisis of 2011-2012, and the ensuing slow global recovery has prompted a growing strand of both theoretical and empirical research aimed at investigating the channels by which uncertainty may affect business cycle fluctuations and the effectiveness of macroeconomic policies, as well as the more operative issue of how uncertainty, a nonmeasurable quantity by nature, can be proxied.

The aim of the present article is three-fold. The following Section reviews the main economic mechanisms which have been theorised when considering the uncertainty/economic activity nexus. Next, the work focuses on the more operative issue of how uncertainty can be proxied by indicators based on observable quantities. Building on the main conclusions derived from both the theoretical and empirical literature surveyed in Sections 2 and 3, the final part of the contribution offers some fresh empirical evidence of the role of uncertainty in shaping macroeconomic fluctuations for the case of the Spanish economy.

\section{THE LINK BETWEEN MACROECONOMIC UNCERTAINTY AND ECONOMIC ACTIVITY}

Economic theory identifies a number of channels through which uncertainty can alter the decisions of private agents (namely, firms and households) and, thus, hinder overall economic activity.

As for the process of capital accumulation, it is widely understood that, in the presence of sunk costs or fixed adjustment costs, investment plans are typically irreversible. With investment opportunities seen as real options, heightened uncertainty increases the value of the option to wait now and invest later (Bernanke, 1983). When there is uncertainty about the future, therefore, entrepreneurs would be better off by postponing (waiting) the decision to invest. Once uncertainty has resolved, however, investment activity is expected to surge, resulting in an overshooting phenomenon (see, e.g., Bloom, 2009). A corollary to 
this argumentation is that uncertainty might lower the elasticity of investment with respect to changes in business conditions generating pro-cyclical productivity growth (Bloom et al., 2014).

Turning to consumers, Romer (1990) and Carroll (1997) show that, under the assumption of convex marginal utility, higher uncertainty can induce households to build up a 'buffer stock' of savings to draw on in periods of relatively low income, thereby reducing their current consumption levels, especially for durable goods, since they are costly to reverse (Caballero, 1990; Romer, 1990; Eberly, 1994). However, this effect is likely to be transitory since it lasts until households have saved the amount they require as insurance against future fluctuations in their income. High uncertainty thus leads households to increase precautionary savings and thereby reduce domestic demand in the short term (FernándezVillaverde et al., 2016) especially when interest rates do not fall enough to stimulate investment plans (Leduc and Liu, 2016).

Besides taking its toll on demand, uncertainty can also impinge on the potential output level of the economy: uncertainty may make workers less willing to seek new jobs, which in turn could lessen productivity growth through less efficient matching of skills to jobs (Lazear and Spletzer, 2012), and/or cause companies to postpone hiring (and firing) decisions (Bloom, 2009). Second, the irreversibility of investment plans may be somewhat alleviated/counteracted by the reversibility of production factors, like labour inputs (Eberly and van Mieghem, 1997; Bontempi et al., 2010).

The real options channel nevertheless rests on a number of critical assumptions, which might not be met, for example, in sectors with rapidly evolving innovation. Under a general equilibrium framework, the uncertaintyinduced overshooting behaviour of investment turns out to be considerably dampened (Bachmann and Bayer, 2014; Born and Pfeifer, 2014). Under specific assumptions, for instance, when firms can easily expand to exploit good conditions and also smoothly contract to bad conditions (the "Oi-Hartman-Abel effect” put forward by Oi, 1961, Hartman, 1972, and Abel, 1983) or when sunk costs can be curbed while the benefits are assumed to be unconstrained (the "growth options effect" posited by Kraft et al., 2017), uncertainty might even affect positively investment levels in the long run. The most recent literature has therefore started exploring the relevance of other potential propagation mechanisms through which uncertainty may hamper economic activity.

Leduc and Liu (2016) propose a transmission mechanism based on the interaction between an option-value channel, that arises from search frictions, and a demand channel, that arises from nominal rigidities. The option-value of waiting effect within a framework allowing for search frictions arises for a similar reason as in the literature of irreversible investment decisions under uncertainty (Bernanke, 1983; Bloom, 2009; Bloom et al., 2012). While nominal 
rigidities help amplify the effect of uncertainty shocks on the unemployment rate through declines in aggregate demand, as in the standard DSGE (Dynamic Stochastic General Equilibrium) model without search frictions (Fernández Villaverde et al., 2015; Basu and Bundick, 2017), search frictions provide an additional mechanism for uncertainty shocks to generate large increases in unemployment via an option-value of waiting channel. Neglecting significant nominal rigidities (search frictions) makes the option-value (demand) channel alone responsible for a much less relevant role of uncertainty shocks in shaping real economic activity, as in Schaal (2017) and Born and Pfeifer (2014). When both mechanisms are simultaneously at work, instead, they interact to amplify the effects of uncertainty shocks.

Another channel through which uncertainty can dampen economic activity relates to the higher cost of finance and lower asset prices due to increasing managerial risk aversion (Panousi and Papanikolaou, 2012) and risk premia (Gilchrist et al., 2010) in times of financial turmoil. With heightened uncertainty, indeed, financial firms typically tend to scale down credit, increase risk premia or even deny credit lines owing to their increased difficulties to evaluate the riskiness of projects to be financed. Allowing for partial irreversibility and fixed adjustment costs in investment activity, as well as financial frictions in a general equilibrium framework, Gilchrist et al. (2014) emphasise the existence of a close interaction between economic uncertainty and changes in financial market conditions which acts as the key propagation mechanism through which uncertainty may hamper aggregate activity in a way consistent with the findings in Arellano et al. (2012) and Christiano et al. (2014), among others. The findings in Caldara et al. (2016) corroborate these conclusions and document that presence of financial constraints magnifies the adverse impact of uncertainty on investment and consumption, pointing to the difficulties related to a clear disentangling between the effects produced by credit cost shocks and those originated from uncertainty ones.

The overall conclusion emerging from the literature surveyed above points to a quite common agreement among scholars with the view that an increase in uncertainty is likely to have a negative impact on economic activity. An important feature of uncertainty is that it cannot be observed directly and, therefore, must be proxied by other variables. Among the different uncertainty measures that have been proposed in the economic literature are proxy measures based on stock market volatility, proxy measures derived from the dispersion in forecasts by professional forecasters, firms and households, and proxy measures tracking the prevalence of terms such as 'economic uncertainty' in the media. Moreover, some of these measures are available in real time and, thus, could help policymakers have a clearer picture of the real-time stance of the economy (Arslan et al., 2015; Rossi and Sekhposyan, 2015; Girardi and Reuter, 2017), while others can be computed only when the actual realization becomes available. As each 
uncertainty indicator has advantages and pitfalls, there is no single widely accepted proxy for uncertainty.

The following Section is devoted to review the main approaches proposed to quantify the level of uncertainty prevailing in the economy over time.

\section{PROXYING MACROECONOMIC UNCERTAINTY}

Since Zarnowitz and Lambros (1987), a popular approach to operationalize uncertainty has been the use of dispersion in individual guesses of economic actors or analysts about the future. When uncertainty is proxied by disagreement, the underlying assumption is that disagreement (an inter-personal measure of dispersion) is able to capture most of the dispersion of aggregate density forecast. Wallis (2005), Boero et al. (2008) and Krüger and Nolte (2016), among others, offer a formal discussion of the link between uncertainty and disagreement. Assuming that the predictive density $f_{i, t}$ of forecaster $i=1, \ldots, n$ at time $t$ has mean $\mu_{i, t}$ and variance $\sigma_{(i, t)}^{2}$, the resulting density combination under an equal weighting scheme across individuals is thus $\bar{f}_{t}=\frac{1}{n} \sum_{i=1}^{n} f_{i, t}$. The variance of $\bar{f}_{t}$, a possible measure of uncertainty, can be derived by resorting to the results for mixture distributions, so that

$$
\bar{\sigma}_{t}^{2}=\frac{1}{n} \sum_{i=1}^{n}\left(\mu_{i, t}-\bar{\mu}_{t}\right)^{2}+\frac{1}{n} \sum_{i=1}^{n} \sigma_{i, t}^{2}=D_{t}+V_{t}
$$

Where $\bar{\mu}_{t}=\frac{1}{n} \sum_{i=1}^{n} \mu_{i, t}$ stands for the average mean forecast. Condition (1) states that the dispersion of aggregate density forecast, $\bar{\sigma}_{t}^{2}$, can be expressed as the sum of a measure of disagreement given by the cross-sectional variance of point forecasts (the $D_{t}$ term), and the average individual variance (the $V_{t}$ term). While the dispersion-based term is obtainable from business and consumer surveys, as well as surveys of professional forecasters, in a quite straightforward way, the $V_{t}$ term is not. Given the difficulties surrounding the computation of the average variance term of (1), the validity of the working hypothesis of proxying uncertainty by disagreement alone hinges upon: (i) the extent to which the $D_{t}$ term dominates over the average individual variance in explaining $\bar{\sigma}_{t}^{2}$; (ii) the degree of association between the $D_{t}$ and $V_{t}$ terms: if the average individual variance is approximately a linear function of disagreement, indeed, then $\bar{\sigma}_{t}^{2}$ is 
also a linear function of disagreement (Bomberger, 1996; Krüger and Nolte, 2016). 1

The operationalization of uncertainty as dispersion can be applied to a number of different variables. Bloom (2009) and Bekaert et al. (2013), for example, focus on the prices of options with identical times to maturity. In particular, Bloom (2009) notes that indicators of implied volatility of share returns are a canonical measure of uncertainty in the financial market. Their dispersion, commonly referred to as stock market volatility, is typically interpreted more broadly as a gauge of economic uncertainty. Another group of researchers (Abel et al., 2016; Rossi and Sekhposyan, 2015) champions the dispersion in professional forecasts of economic aggregates (real GDP or inflation) by drawing upon information from the individual histogram of survey respondents. Bachmann et al. (2013), by contrast, tap the richness of data gathered in business tendency surveys, deriving uncertainty from the dispersion of businesses' expectations for the future. In spite of their popularity, there is a downside to all dispersion-based uncertainty measures, notably that they are not solely driven by changes in the level of uncertainty. An important additional factor determining their evolvement is, for instance, the degree of genuine disagreement among the actors inquired. Professional forecasters might have very different forecasts about future economic growth, but, based on their models, be completely sure about them. In such a case, the dispersion of forecasts seems to signal a high level of uncertainty, while actually the indicator only reports elevated disagreement levels. It is important to keep these limitations in mind when interpreting dispersion-based uncertainty indicators. Yet another strategy is to purposefully collect new data for the explicit aim of measuring uncertainty, rather than deriving it from existing datasets (Alexopoulos and Cohen, 2015; Baker et al., 2016). Baker et al. (2016) arguably the spearheads of this approach, for example, construct an economic policy uncertainty indicator based on the number of newspaper articles which feature a combination of search terms which suggest the presence of economic policy uncertainty. The downside of such an approach is obviously the nonnegligible degree of subjectivity involved in its execution (e.g. the choice of newspapers, the search terms).

Departing from the criticism of the fact that the vast majority of uncertainty proxies are based on a single economic indicator, Jurado et al. (2015) propose an alternative approach to the measurement of uncertainty by tracking the magnitude of errors in forecasting a large set of macro-economic series over

\footnotetext{
${ }^{1}$ In the case of nonlinear combination schemes of individual densities, the role of disagreement is less clear, although Krüger (2017) and Gneiting and Ranjan (2013) point out that disagreement might be useful even in this context through its potential correlation with the average variance provided that the relationship between uncertainty and disagreement remains broadly stable along the business cycle (Lahiri and Sheng, 2010).
} 
time. This reliance on several variables arguably decreases the probability of the indicator signalling false positives (i.e. signalling high uncertainty where there is none) or negatives (i.e. failure to detect mounting uncertainty). Assuming that wrong forecasts reflect uncertainty, a rise in the average forecasting error of all macroeconomic series is interpreted as a signal of increased uncertainty at the time the forecast was prepared. The obvious shortcoming of the approach is its ex-post nature, with uncertainty levels only measurable with hindsight. Likewise, Girardi and Reuter (2017) try to distil the information contained in a large set of publicly available survey data, rather than hard-to-acquire micro survey data (i.e. non-aggregated data displaying the responses of individual firms/consumers). Furthermore, deviating from survey indicators presented so far and in line with Jurado et al. (2015), as well as Glass and Fritsche's (2014) approach of deriving uncertainty from developments in many, rather than a few, variables, their indicators are based on the assessments of actors in a multitude of economic sectors (industry, services, retail trade, and construction) and across consumers.

Despite the plurality of approaches to construct proxies to quantify the level of uncertainty, there is a quite general consensus on how to judge the plausibility of a given uncertainty proxy. Given the latent character of the concept of uncertainty, there is no track record of 'known' uncertainty levels in the past (Bloom, 2014). One can therefore inquire whether the indicators' evolvement is plausible and verify whether they coincide with potentially relevant political/economic events. A more formal assessment of the role exerted by a given uncertainty measure in explaining macroeconomic dynamics is carried out within a Vector Autoregressive (VAR) framework (see, among others, Bloom, 2009; Bachmann et al., 2013; Jurado et al., 2015, Baker et al., 2016; Girardi and Reuter, 2017) once the occurrence of rare, large one-off uncertainty shocks has been identified.

In keeping with the relevant empirical literature on the subject, Section 4 presents some evidence on the impact of uncertainty shocks on the level of economic activity for the case of Spain.

\section{MACROECONOMIC UNCERTAINTY AND ECONOMIC ACTIVITY: SOME EVIDENCE FROM SPAIN}

Empirical analyses on the effects of uncertainty shocks on economic activity have mostly been focused on the US economy (Bloom, 2009; Jurado et al., 2015, Baker et al., 2016, among others). Nonetheless, a growing number of contribution has started assessing the macroeconomic impact of uncertainty for other economies/regions (including Spain). ${ }^{2}$

\footnotetext{
${ }^{2}$ For instance, Bachmann et al. (2013) compare evidence from the USA and Germany; Arslan et al. (2015) and Cerda et al. (2016) focus on the cases of Turkey and Chile, respectively; Haddow et al.
} 
Exploiting the idea that macro-uncertainty can be directly derived from the opinions of economic agents (firms and consumers), here we broadly follow Girardi and Reuter (2017) to proxy uncertainty through a survey-based indicator for the case of the Spanish economy. The measure is based on the concepts underlying already existing uncertainty indicators, but differs from them in so far as it is (i) computable on the basis of publicly available data, (ii) derived from the assessments of actors in a multitude of economic sectors, (iii) available in real-time, rather than ex-post. Moreover, assuming that uncertainty is a human condition with potential effects across all branches of the economy, the proposed indicator is assessed in terms of their bearing on overall GDP, rather than more indirect proxies for the level of economic activity like industrial production, gross fixed capital formation or employment.

Specifically, the proposed indicator builds on the information content conveyed by business surveys referring to the development of selling prices and employment in four sectors (industry, services, retail trade, construction), export orders and production in industry, demand in services, as well as orders placed with suppliers and sales in retail trade. In respect of the consumer survey, questions inquiry about households' individual economic situation (their financial position, the likelihood of them saving money, making major purchases, buying a car, building a house or embarking on renovations), as well as questions about macro-economic developments, namely the general economic situation, prices and unemployment. See, for further details, European Commission (2015).

In its essence, the indicator is an extension of Bachmann et al. (2013) and is based on all (monthly and quarterly) forward-looking questions contained in the Joint Harmonised EU Programme of Business and Consumer Surveys (EU BCS) programme. Its construction is based on a three-step procedure. The first step consists of calculating the dispersion of the share of positive and negative responses (as measured by standard deviation) for every survey questions in a given month. In contrast with Girardi and Reuter (2017), however, the questionspecific dispersion measures at a given date are scaled by their corresponding

(2013) analyse the case of the UK economy; Glass and Fritsche (2014) and Girardi and Reuter (2017) consider the case of the euro-area aggregate. As for the individual euro-area Member States, the empirical evidence is still rather limited. Manteu and Serra (2017) study the case of the Portuguese economy, while Schneider and Giorno (2014) present a comparative analysis of the impact of uncertainty for Greece, Portugal and Ireland by proxying uncertainty through stock market volatilities. A quite recent contribution by Meinen and Röhe (2017) constitutes an encompassing investigation of the effect of uncertainty as measured by the approaches put forward by Bloom (2009), Rossi and Sekhposyan (2015), Bachmann et al. (2013), Baker et al. (2016) and Jurado et al. (2015) for the case of the four largest euro-area countries (namely, Germany, France, Italy, and Spain). Their results document an overall detrimental effect of uncertainty shocks on the real economy (as measured by gross fixed capital formation), but put in doubt the "wait-and-see" hypothesis of a rebound in real activity following an initial decline after an uncertainty shock. 
average values (expressed in terms of diffusion index). ${ }^{3}$ The resulting standardised measure of dispersion is a-dimensional by nature, thus easing that the aggregation across questions (which is carried out by simple averaging question-specific standardised dispersion measures). Finally, the monthly indicator is converted into a quarterly series by taking average values and then rescaled such that its first value (the 1999q1 in the present context) is set to 100 so as to enable an easier interpretation of its time evolvement.

A graphical inspection of the evolution over time of the proposed uncertainty measure can inquire whether the shape is plausible. The point of departure is the identification of peaks in the uncertainty indicators (i.e. quarters in which the uncertainty indicator exceeds a threshold for outlier detection given by median plus 2.5 times the mean absolute deviation, as devised by Leys et al., 2013) and subsequently the corroboration of whether or not they coincide with potentially relevant political/economic events. The grey bars in Figure 1 flag such high uncertainty periods.

There are only two striking uncertainty periods, notably in 2008/2009 and 2012/2013. These are clearly in line with a commonly-held view that both the eruption of the financial crisis (Lehman Brothers bankruptcy in 2008q3) and the subsequent quarters of turmoil and the European sovereign debt crisis have been major uncertainty-enhanced episodes. Moreover, the evolution over time of the proposed indicator looks remarkably similar to the synthetic indicator of economic uncertainty recently proposed by Gil et al. (2017) for the case of Spain. As the uncertainty indicator peaks in occurrence of times of economic slack, it displays a solid, negative, correlation with GDP growth (no matter if expressed in quarter-on-quarter or year-on-year rates), pointing to a clear countercyclical evolution over time in a way consistent with the prescriptions of a large number of theoretical models (see, among others, Van Nieuwerburgh and Veldkamp, 2006; Bachmann and Moscarini, 2011; Fostel and Geanakoplos, 2012; Decker et al., 2016; Tian, 2015).

Overall, these insights are important pre-conditions for the ensuing empirical analysis, which introduces the proposed indicator in a multivariate time-series framework to assess what impact on GDP it would exert in the case of an unanticipated shift in uncertainty.

\footnotetext{
${ }^{3}$ This step aims at controlling for the so-called "by-product" phenomenon in the jargon of Bachmann et al. (2013), that is the remark that uncertainty periods are often associated with very low level of confidence. Indeed, it might be that high uncertainty is detrimental to real economic developments, but also that in times of crisis households and firms tend to revise down their central expectation of the economic outlook, while at the same time attaching a higher probability to extreme events occurring to either side of the (more pessimistic) central tendency.
} 
Figure 1

Survey-based uncertainty indicators and major uncertainty periods

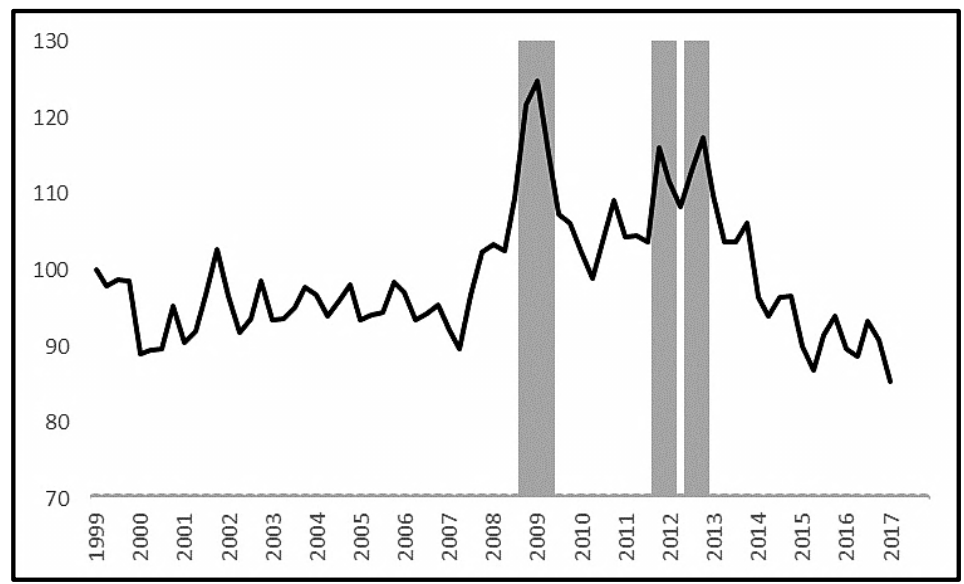

Note: Grey bars identify extreme uncertainty periods defined as the quarters in which the uncertainty indicator rises by at least the median plus 2.5 times the mean absolute deviation.

Source: Own elaboration.

In keeping with the relevant empirical literature on the subject (Bloom, 2009; Bachmann et al., 2013; Jurado et al., 2015, Baker et al., 2016), we conduct such a quantitative assessment within a (recursive) VAR framework. In particular, the model is estimated with two lags over the period from 1999q1 to 2017q1, and includes a constant term as deterministic component, with a simulation horizon set equal to 20 quarters (five years). All data are seasonally adjusted and retrieved via Datastream. The simulated model resembles the larger specification in Bloom (2009) and Bachmann et al. (2013) where variabels are ordered as follows: the uncertainty indicatorthe short-term interest rate, nominal wages, the consumer price index, total hours worked, total employment, and real GDP. In contrast to Bloom (2009) and Bachmann et al. (2013), however, the proposed specification does not include the level of confidence as additional variable feeding the system, as the proposed uncertainty indicator controls for "first moment" effects (Bachmann et al., 2013) by construction. ${ }^{4}$ Figure 2 shows the response of GDP to an uncertainty shock, where the shaded areas represent the $90 \%$ bias-corrected bootstrap confidence intervals computed as suggested by Kilian (1998).

\footnotetext{
${ }^{4}$ We have also augmented the VAR specification by including credit costs as in Caldara et al. (2016) and Girardi and Reuter (2017), among others. However, extending the system to account for the effect of credit costs does not alter qualitatively the results presented in this Section.
} 
Figure 2

GDP response to an uncertainty shock

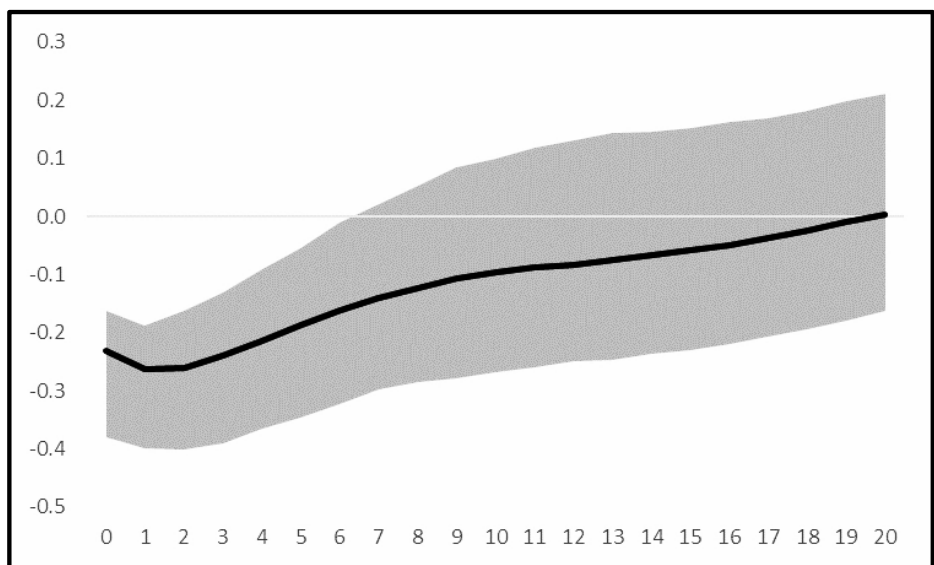

Note. The vertical axis indicates percentage deviations of real GDP from the baseline path. The horizontal axis denotes simulation quarters. The shaded areas represent the $90 \%$ bias-corrected bootstrap confidence intervals computed as suggested by Kilian (1998).

Source: Own elaboration.

The graph documents a reduction of the level of aggregate activity by about $0.2 \%$ on impact. The contraction peaks one-two quarters after the shock and then is gradually absorbed. After five years, the level of activity tends to revert to its pre-shock level. Compared to the existing literature on the empirical impact of uncertainty on economic output, the results appear in line with the evidence reported in Bloom (2009) for the US and Girardi and Reuter (2017) for the euro area aggregate. Similar evidence in terms of both dynamics and magnitudes is also reported by Gil et al. (2017) for the specific case of Spain. Contrasting with Bloom's paper though, the results do not corroborate the existence of an overshooting phenomenon, where a rise in uncertainty at first depresses real activity and then increases it above the pre-shock level.

Moreover, uncertainty accounts for a non-negligible share of GDP variation. When looking at the evolvement of the contribution over time, a concave development emerges, with the contribution to GDP variability of about $17 \%$ which rises to a peak at $21 \%$ in quarter 1 and subsequently vanishing towards the end of the simulation horizon. Overall, the results for the Spanish case are broadly in line with the observations of Bachmann et al. (2013), Jurado et al. (2015) and Girardi and Reuter (2017), who report, for the cases of Germany, the USA and the euro area aggregate, a concave shape of the impact of uncertainty shocks on GDP variability, as well as magnitudes of the effect in the range of 10 to $40 \%$ of the variability in economic output. 


\section{CONCLUDING REMARKS}

This article has surveyed the literature focusing on the transmission channels through which uncertainty shocks hinder economic activity followed by a brief review of the main approaches that have been proposed to construct proxies for macroeconomic uncertainty. Using survey data for both business sectors and consumers, we have presented an uncertainty indicator for the case of the Spain. The proposed uncertainty index exhibits peaks in the occurrence of major uncertainty-enhancing events that have hit the Spanish economy in the period subsequent the onset of the European Monetary Union. Our index also shows a clear counter-cyclical evolution over time. This pattern is consistent with the theoretical view according to which recessions are typically periods of severed business practices and consumers' attitudes towards major purchases, the reestablishment of which thereby generates uncertainty. Using data for the Spanish economy, the evidence shows that uncertainty shocks hinder economic activity in the short run: real output declines and subsequently recovers almost monotonically towards the pre-shock level.

Overall, the macroeconomic impact of uncertainty is an issue with a multifaced nature. It comes as no surprise that the strand of literature aimed at explaining the channels through (and quantifying the extent to) which uncertainty hinders economic activity continues growing at an impressive pace. In this respect, a recent strand of literature has started investigating the impact of heightened uncertainty on the effectiveness of macroeconomic policies. A number of contributions has indeed shown that uncertainty surrounding fiscal or monetary policies exerts a significant effect on macroeconomic activity (FernándezVillaverde et al., 2011; Mumtaz and Zanetti, 2013; Fernández-Villaverde et al., 2015). As for the case of monetary policy, for instance, the aforementioned reduced elasticity of investment to changes in its driving forces (for instance, the level of interest rates) in high uncertainty periods would require a more substantial cut in interest rates to stimulate investment plans as in normal times (Aastveit et al., 2014). At the same time, periods of heightened uncertainty could also require specific measures aimed at reducing the level of uncertainty itself, which would in turn make other policy measures more effective. On a more general perspective, economic research is paying growing attention to the international dimension of uncertainty with several studies documenting that uncertainty shocks originating in large economies can propagate across borders; moreover, large uncertainty shocks are international in nature (Colombo, 2013; Kamber, et al., 2016; Klößner and Sekkel, 2014; Davis, 2016). Furthermore, spikes in uncertainty seem to affect international capital flows (Gourio et al., 2015) and the response to uncertainty shocks tends to differ among countries. Emerging economies (with less developed financial markets) tend to experience more persistent downturns (Carrière-Swallow and Céspedes, 2013). All in all, 
these issues leave room for further fruitful research aimed at sharpening our understanding on how (and when) uncertainty shocks reverberate across the economy.

\section{BIBLIOGRAPHY REFERENCES}

AASTVEIT, K.A.; NATVIK, G.J. and SOLA, S. (2013). "Economic Uncertainty and the Effectiveness of Monetary Policy". Norges Bank Working Paper, 17.

ABEL, A.B. (1983). "Optimal Investment Under Uncertainty". The American Economic Review, 73, pp. 228-233.

ABEL, J.; RICH, R.; SONG, J. and TRACY, J. (2016). "The Measurement and Behavior of Uncertainty: Evidence from the ECB Survey of Professional Forecasters". Journal of Applied Econometrics, 31, pp. 533-550.

ALEXOPOULOS, M. and COHEN, J. (2015). "The Power of Print: Uncertainty Shocks, Markets, and the Economy". International Review of Economics and Finance, 40, pp. 828.

ARELLANO, C.; BAI, Y. and KEHOE, P.J. (2012). "Financial Markets and Fluctuations in Volatility". Federal Reserve Bank of Minneapolis Staff Report, 466.

ARSLAN, Y.; ATABEK, A.; HULAGU, T. AND ŞAHINÖZ, S. (2015). "Expectation Errors, Uncertainty, and Economic Activity". Oxford Economic Papers, 67, pp. 634-660.

BACHMANN, R. and BAYER, C. (2014). "Investment Dispersion and the Business Cycle". The American Economic Review, 104, pp. 1392-1416.

BACHMANN R., ELSTNER, S. and SIMS, E.R. (2013). "Uncertainty and Economic Activity: Evidence from Business Survey Data". American Economic Journal: Macroeconomics, 5, pp. 217-249.

BACHMANN, R. and MOSCARINI, G. (2011). "Business Cycles and Endogenous Uncertainty". Yale mimeo.

BAKER, S.R.; BLOOM, N. and DAVIS, S.J. (2016). "Measuring Economic Policy Uncertainty". The Quarterly Journal of Economics, 131, pp. 1593-1636.

BASU, S. and BUNDICK, B. (2017). "Uncertainty Shocks in a Model of Effective Demand". Econometrica, DOI: 10.3982/ECTA13960.

BEKAERT, G.; HOEROVA, M. and LO DUCA, M. (2013). "Risk, Uncertainty and Monetary Policy". Journal of Monetary Economics, 60, pp. 771-788.

BERNANKE, B.S. (1983). "Irreversibility, Uncertainty and Cyclical Investment". Quarterly Journal of Economics, 98, pp. 85-106.

BLOOM, N. (2009). "The Impact of Uncertainty Shocks". Econometrica, 77, pp. 623-685.

BLOOM, N. (2014). "Fluctuations in Uncertainty". Journal of Economic Perspectives, 28, pp. 153-176.

BLOOM, N.; FLOETOTTO, M.; JAIMOVICH, N.; SAPORTA-EKSTEN, I. and TERRY, S. (2014). "Really Uncertain Business Cycles". US Census Bureau Center for Economic Studies Paper, CES-WP-14-18. 
BOERO, G.; Smith, J. And WALLIS K.F. (2008). "Uncertainty and disagreement in economic prediction: the Bank of England Survey of External Forecasters". The Economic Journal, 118, pp. 1107-1127.

BOMBERGER, W.A. (1996). "Disagreement as a Measure of Uncertainty". Journal of Money, Credit and Banking, 28, pp. 381-392.

BONTEMPI, M.E.; GOLINELLI, R. and PARIGI, G. (2010). "Why Demand Uncertainty Curbs Investment: Evidence from a Panel of Italian Manufacturing Firms". Journal of Macroeconomics, 32, pp. 218-238.

BORN, B. and PFEIFER, J. (2014). "Policy Risk and the Business Cycle". Journal of Monetary Economics, 68, pp. 68-85.

CALDARA, D.; FUENTES-ALBERO, C.; GILCHRIST, S. and ZAKRAJSEK, E. (2016). "The Macroeconomic Implications of Financial and Uncertainty Shock". European Economic Review, 88, pp. 185-207.

CERDA, R.; SILVA, A. and VALENTE, J.T. (2016). "Economic Uncertainty Impact in a Small Open Economy: The Case of Chile". Clapes UC Working Paper, 25.

CHRISTIANO, L.J.; MOTTO, R. and ROSTAGNO, M. (2014). "Risk Shocks". The American Economic Review, 104, pp. 27-65.

COLOMBO, V. (2013). "Economic Policy Uncertainty in the US: Does It Matter for the Euro Area?". Economics Letters, 121, pp. 39-42.

CARROLL C. (1997). "Buffer-stock Saving and the Life Cycle/Permanent Income Hypothesis". The Journal of Economics, 112, pp. 1-55.

CABALLERO, R. (1990). "Consumption Puzzles and Precautionary Savings". Journal of Monetary Economics, 25, pp. 113-136.

CARRIĖRE-SWALLOW, Y. and CÉSPEDES, L.F. (2013). "The impact of uncertainty shocks in emerging economies". Journal of International Economics, 90, pp. 316-325.

DAVIS, S.J. (2016). "An Index of Global Economic Policy Uncertainty". National Bureau of Economic Research Working Paper, 22740.

DECKER, R; D'ERASMO, P. and MOSCOSO BOEDO, H.J. (2016). "Market Exposure and Endogenous Firm Volatility over the Business Cycle". American Economic Journal: Macroeconomics, 8, pp. 148-198.

EBERLY, J. (1994). "Adjustment of Consumers' Durables Stocks: Evidence from Automobile Purchases". Journal of Political Economy, 102, pp. 403-436.

EBERLY, J.C. and VAN MIEGHEM, J.A. (1997). "Multi-factor Dynamic Investment and Uncertainty". Journal of Economic Theory, 75, pp. 345-387.

EUROPEAN COMMISSION (2015). The Joint Harmonised EU Programme of Business and Consumer Surveys (User Guide).

FERNÁNDEZ-VILLAVERDE J.; GUERRÓN-QUINTANA, P.; KUESTER, K. and RUBIORAMÍREZ J.F. (2015). "Fiscal Volatility Shocks and Economic Activity". The American Economic Review, 105, pp. 3352-3384.

FERNÁNDEZ-VILLAVERDE, J.; GUERRÓN-QUINTANA, P.; RUBIO-RAMÍREZ, J. and URIBE, M. (2011). "Risk Matters: The Real Effects of Volatility Shocks", The American Economic Review, 101, pp. 2530-2561.

FOSTEL, A. and GEANAKOPLOS, J. (2012). "Why Does Bad News Increase Volatility and Decrease Leverage?". Journal of Economic Theory,147, pp. 501-525. 
GIL, M.; PÉREZ, J.J. and URTASUN, A. (2017). "Macroeconomic uncertainty: measurement and impact on the Spanish economy". Banco de España Analitical Articles, February.

GILCHRIST, S.; SIM, J.W. and ZAKRAJSEK E. (2014). "Uncertainty, Financial Frictions, and Investment Dynamics". National Bureau of Economic Research Working Paper, 20038.

GIRARDI, A. and REUTER, A. (2017). "New Uncertainty Measures for the Euro Area using Survey Data". Oxford Economic Papers, 69, pp. 278-300.

GLASS, K. and FRITSCHE, U. (2014). "Real-Time Information Content of Macroeconomic Data and Uncertainty: An Application to the Euro Area". DEP (Socioeconomics) Discussion Papers, Macroeconomics and Finance Series, 6.

GNEITING, T. AND RANJAN, R. (2013). "Combining predictive distributions". Electronic Journal of Statistics, 7, pp. 1747-1782.

GOURIO, F.; SIEMER, M. and VERDELHAN, A. (2015). "Uncertainty and international capital flows". Mimeo.

HADDOW, A.; HARE, C.; HOOLEY, J. and SHAKIR, T. (2013). "Macroeconomic Uncertainty: What Is It, How Can We Measure It and Why Does It Matter?". Bank of England Quarterly Bulletin, 53, pp. 100-109.

HARTMAN, R. (1972). "The Effects of Price and Cost Uncertainty on Investment". Journal of Economic Theory, 5, pp. 258-266.

JURADO, K.; LUDVIGSON, S. and NG, S. (2015). "Measuring Uncertainty". The American Economic Review, 105, pp. 1177-1216.

KAMBER, G., KARAGEDIKLI, Ö. and RYAN, M. (2016). "International Spill-overs of Uncertainty Shocks: Evidence from a FAVAR". Australian National University, CEMA Working Paper, 61.

KILIAN, L. (1998). "Small-Sample Confidence Intervals for Impulse Response Functions". Review of Economics and Statistics, 80, pp. 218-230.

KLÖßNER, S. and SEKKEL, R. (2014). "International Spillovers of Policy Uncertainty". Economics Letters, 124, pp. 508-512.

KRAFT, H.; SCHWARTZ, E.S. and WEISS, F., (2017). "Growth Options and Firm Valuation". European Financial Management; DOI: 10.1111/EUFM.12141.

KRÜGER, F. (2017). "Survey based Forecast Distributions for Euro Area Growth and Inflation: Ensembles versus Histograms". Empirical Economics, 53, pp. 235-246.

KRÜGER, F. and NOLTE, I. (2016). "Disagreement versus uncertainty: Evidence from distribution forecasts". Journal of Banking \& Finance, 72, issue S, pp. S172-S186.

LAHIRI, K. and SHENG, X. (2010). "Measuring forecast uncertainty by disagreement: The missing link". Journal of Applied Econometrics, 25, pp. 514-538.

LAZEAR E.P. and SPLETZER, J.R. (2012). "Hiring, Churn and the Business Cycle". The American Economic Review, 102, pp. 575-579.

LEDUC, S. and LIU, Z. (2016). "Uncertainty Shocks Are Aggregate Demand Shocks". Journal of Monetary Economics, 82, pp. 20-35.

LEYS, C.; LEY, C.; KLEIN, O.; BERNARD, P. and LICATA, L. (2013). "Detecting Outliers: Do not Use Standard Deviation around the Mean, Use Absolute Deviation around the Median". Journal of Experimental Social Psychology, 49, pp. 764-766.

MANTEU, C. and SERRA, S. (2017). "Impact of Uncertainty Measures on the Portuguese Economy". Banco de Portugal Working Paper, 9. 
MEINEN, P. and RÖHE, O. (2017). "On Measuring Uncertainty and its Impact on Investment: Cross-country Evidence from the Euro Area". European Economic Review, 92, pp. 161-179.

MUMTAZ H. and ZANETTI, F. (2013). "The Impact of the Volatility of Monetary Policy Shocks". Journal of Money, Credit, and Banking, 45, pp. 535-558.

OI, W. (1961). "The Desirability of Price Instability Under Perfect Competition". Econometrica, 29, pp: 58-64.

PANOUSI, V. and PAPANIKOLAOU, D. (2012). "Investment, Idiosyncratic Risk, and Ownership". The Journal of Finance, 67, pp. 1113-1148.

ROMER C. (1990). "The Great Crash and the Onset of the Great Depression". The Quarterly Journal of Economics, 105, pp. 597-624.

ROSSI, B. and SEKHPOSYAN, T. (2015). "Macroeconomic Uncertainty Indices Based on Nowcast and Forecast Error Distributions". The American Economic Review, 105, pp. 650-655.

SCHAAL E., (2017). "Uncertainty and Unemployment". Econometrica, forthcoming.

SCHNEIDER, J.-D. and GIORNO, C. (2014). "Economic Uncertainties and their Impact on Activity in Greece compared with Ireland and Portugal". OECD Economics Department Working Papers, 1151.

TIAN, C. (2015). "Riskiness, Endogenous Productivity Dispersion and Business Cycles". Journal of Economic Dynamics and Control, 57, pp. 227-249.

VAN NIEUWERBURGH, S. and VELDKAMP, L. (2006). "Learning Asymmetries in Real Business Cycles". Journal of Monetary Economics, 53, pp. 753-772.

WALLIS, K.F. (2005). "Combining Density and Interval Forecasts: A Modest Proposal". Oxford Bulletin of Economics and Statistics, 67 (supplement), pp. 983-994.

ZARNOWITZ, V. and LAMBROS, L.A. (1987). "Consensus and uncertainty in economic prediction". Journal of Political Economy, 95, pp. 591-621. 